\title{
DEIKSIS PERSONA PADA KARANGAN NARASI SISWA KELAS X SMK WIRA BUANA 2
}

\author{
Chadis \\ Program Studi Pendidikan Bahasa Indonesia, \\ Fakultas Bahasa dan Seni, Universitas Indraprasta PGRI \\ chadis_cila@yahoo.com
}

\begin{abstract}
Abstrak
Penelitian ini bertujuan untuk mengetahui jenis-jenis deiksis persona yang digunakan siswa kelas $\mathrm{X}$ Sekolah Menengah Kejuruan (SMK) Wira Buana 2. Penelitian ini menggunakan pendekatan deskriptif kualitatif dengan teknik analisis isi. Berdasarkan hasil analisis yang telah dilakukan pada karangan narasi yang dibuat oleh siswa kelas X SMK Wira Buana 2, ditemukan banyaknya penggunaan kata berdeiksis persona dengan total 514 temuan. Sebagai perinciaanya, penggunaan deiksis persona pertama sebanyak 496 kata dengan hasil persentase sebesar 96.50\%. Penggunaan deiksis persona kedua sebanyak 2 kata dengan hasil persentase $0,39 \%$ dan penggunaan deiksis persona ketiga sebanyak 16 kata dengan hasil persentase $3,11 \%$.
\end{abstract}

Kata Kunci: deiksis persona, persona pertama, persona kedua, persona ketiga, karangan narasi

\begin{abstract}
This research aims to determine the types of person deixis used by class X students of Wira Buana 2 Vocational Secondary School (SMK). This study used a qualitative descriptive approach with content analysis techniques. Based on the results of the analysis that has been carried out on the narrative essay made by class X students of Wira Buana 2 Vocational Secondary School (SMK), it is found that there are many uses of the word person deixis with a total of 514 words. As the details, the use of the first-person deixis is 496 words with a percentage of $96.50 \%$. The use of second person deixis is 2 words with a percentage result of $0.39 \%$ and the use of third person deixis is 16 words with a percentage of $3.11 \%$.
\end{abstract}

Keywords: person deixis, first person, second person, third person, narrative essay.

\section{PENDAHULUAN}

Menulis merupakan kegiatan menuangkan isi hati penulis ke dalam bentuk tulisan. Kemampuan seseorang dalam menuangkan isi hatinya ke dalam tulisan sangatlah berbeda-beda. Hal ini terjadi karena adanya perbedaan latar belakang penulis, sehingga kualitas dan mutu yang dihasilkan setiap orang juga akan berbeda-beda. Oleh sebab itu, untuk mendapatkan kemampuan yang baik dalam menulis harus memerhatikan kembali proses pembelajaran yang lebih merinci dan latihan secara intensif khususnya para siswa.

Menyadari akan pentingnya keterampilan menulis, diharapkan siswa dapat belajar mengembangkan kemampuan berbahasa. Penerapan kegiatan menulis pada pembelajaran di sekolah dapat dilakukan dengan penulisan karangan. Dalam menulis karangan, terdapat pula aturan-aturan yang telah ditetapkan. Penulisan kalimat 
yang terdapat dalam suatu paragraf merupakan satu hal yang penting. Jika tidak diperhatikan dengan baik, maka dapat terjadi kesalahan yang membuat kalimat-kalimat tersebut tidak kohesif.

Karangan yang baik ditentukan oleh setiap kalimat yang membentuk paragraf. Selain dilihat dari pemilihan kata, ejaan dan tanda baca yang tepat, sebuah kalimat dapat dikategorikan sebagai kalimat yang baik yaitu dengan adanya kata-kata penunjuk atau deiksis. Kata-kata penunjuk yang dimaksud merupakan kata-kata yang referennya tidak tetap. Kata tersebut dapat berpindah dari satu rujukan kepada rujukan lain atau dapat berubah ukurannya, kata-kata seperti ini disebut kata-kata dieksis.

Deiksis memiliki keterkaitan dengan konteks. Konteks merupakan faktor di luar dari segi kebahasaan, seperti mengetahui siapa yang sedang berbicara, siapa lawan tuturnya, bagaimana situasi dan kondisi dalam suatu tindak tutur dan sebagainya. Jadi, deiksis tidak dapat terlepas dari konteks.

Deiksis terbagi atas lima jenis, di antaranya deiksis orang (persona), deiksis waktu, deiksis tempat, deiksis sosial dan deiksis wacana. Dalam artikel ini, penulis hanya memfokuskan pada deiksis orang (persona). Deiksis orang berkenaan dengan penggunaan kata ganti persona, seperti saya (kata ganti persona pertama), kamu (kata ganti persona kedua) dan mereka (kata ganti persona ketiga).

Peranan guru Bahasa Indonesia dalam mengajar di kelas menjadi satu hal penting yang memengaruhi pengetahuan bahkan keterampilan siswa dalam menguasai berbagai materi kebahasaan, seperti penggunaan deiksis dan menulis karangan. Dalam membuat karangan, siswa dilatih untuk membuat paragraf yang berisikan kalimat yang padu dan baik. Di samping itu, karangan terbagi dalam beberapa jenis, salah satunya karangan narasi.

Karangan narasi ialah karangan yang berusaha menciptakan, mengisahkan, merangkaikan perbuatan manusia dalam sebuah peristiwa secara kronologis atau yang berlangsung dalam suatu kesatuan waktu. Karangan ini merupakan satu dari lima jenis karangan yang terpopuler di kalangan siswa dikarenakan mudah dalam proses pembuatannya. Oleh karena itu, karangan narasi dapat menjadi pilihan yang tepat sebagai media pembelajaran siswa, karena pada karangan narasi terdapat kata-kata berdeiksis yang digunakan.

Kata Deiksis berasal dari bahasa Yunani, yaitu deiktitos yang berarti 'hal penunjukan secara langsung.' Deiksis berakar pada persona pertama tunggal dan menyangkut persona, waktu dan ruang. (Verhaar, 2006:397). Begitupun dengan Kridalaksana (2009:45) yang memiliki kesamaan pendapat yaitu "Deiksis adalah hal atau fungsi yang menunjuk sesuatu di luar bahasa yang menyangkut persona waktu dan ruang." Departemen Pendidikan Nasional (2011:305), deiksis berarti hal atau fungsi menunjuk sesuatu di luar bahasa; kata yang mengacu kepada persona, waktu, dan tempat suatu tuturan.

Putrayasa (2014:39) berpendapat bahwa "Deiksis adalah kata yang tidak memiliki referen atau acuan yang tetap." Kemudian, menurut Alwi (2003:42) "Deiksis adalah gejala semantis yang terdapat pada kata atau konstruksi yang hanya dapat ditafsirkan acuannya dengan memperhitungkan situasi pembicara." Pendapat lainnya berasal dari Yule (2006:13) Deiksis berarti penunjukan melalui bahasa. Berdasarkan pendapat di atas dapat disimpulkan bahwa, deiksis adalah penunjukan melalui bahasa yang memiliki referen atau acuan yang dapat berpindah-pindah 
atau tidak tetap, yang hanya dapat ditafsirkan acuannya dengan memperhatikan situasi pembicaraan.

Konteks merupakan hal yang sangat berkaitan dan terikat dengan katakata berdeiksis. Seperti yang dikemukan oleh Kushartanti dkk. (2005:111) bahwa "Deiksis adalah cara merujuk pada suatu hal yang berkaitan erat dengan konteks penutur. Dengan demikian, ada rujukan yang berasal dari penutur, dekat dengan penutur dan jauh dari penutur." Deiksis menunjukkan cara dimana bahasa mengodekan atau menggramatikalkan unsur-unsur dari konteks ujaran atau peristiwa tutur dan karena itu juga menunjukan cara-cara dimana interpretasi terhadap ujaran tergantung kepada analis terhadap konteks ujaran itu (Putrayasa, 2014:39).

Deiksis termasuk ke dalam ranah pragmatik karena secara langsung mengacu kepada hubungan antara struktur bahasa dan konteks dimana deiksis itu digunakan. Selain itu, deiksis itu meliputi banyak petunjuk tentang tempat, persona, waktu penunjuk yang digunakan berkaitan dengan konteks yang ada. Tanpa adanya konteks, deiksis dapat membingungkan orang atau dapat menimbulkan ambiguitas.

Deiksis adalah kata tertentu yang kadang-kadang disertai dengan perbuatan tingkah laku pembicara berupa gesture atau mimik muka untuk menyatakan makna kata yang diucapkan lebih jelas (Ihsan, 2011:73). Pada saat menggunakan kata-kata deiksis seperti ini, itu, saya, kamu, di sana, sekarang dan lain sebagianya, maka seorang dapat mengucapkannya dengan tanda berupa anggota tubuh seperti tangan, jari dan kepala. Misalnya seseorang memanggil saya, tetapi saya masih ragu, apakah seseorang tersebut memanggil saya atau tidak, maka saya akan berkata saya? Kepada orang tersebut dengan kemungkinan saya menggunakan tangan atau jari yang menunjuk ke arah saya. Begitupun dengan kata ini dan di sana yang memungkinkan seseorang menunjuk benda atau tempat.

Berdasarkan penjelasan di atas dapat disimpulkan bahwa deiksis adalah kata atau ungkapan yang referennya dapat berpindah-pindah atau tidak tetap yang selalu berkaitan dengan adanya konteks agar maknanya dapat dipahami tergantung pada siapa yang menjadi penutur, waktu bagaimana dan tempat dimana seorang melakukan kegiatan tutur. Mengucapkan kata deiktis memungkinkan adanya perbuatan atau tingkah laku seperti menunjuk misalnya menggunakan tangan atau jari.

\section{METODE PENELITIAN}

Jika dilihat dari jenisnya, pendekatan yang digunakan dalam penelitian ini adalah pendekatan deskriptif kualitatif. Dengan pendekatan ini, penulis melakukan kajian langsung terhadap penggunaan deiksis pada karangan narasi peserta didik kelas $\mathrm{X}$ di SMK Wira Buana 2. Data penelitian ini dilakukan saat kegiatan pembelajaran Bahasa Indonesia di kelas sesuai dengan jam pelajaran. Data penelitian ini juga diperoleh dari karangan narasi yang dibuat siswa sesuai dengan tema yang telah ditentukan.

Teknik yang digunakan dalam penelitian ini adalah teknik deskriptifkualitatif dengan teknik analisis isi. Teknik deskriptif menganalisis dengan menggambarkan kata-kata deiksis dari karangan narasi siswa. Setelah dianalisis dan dipersentase, data akan dijadikan pedoman untuk membuat simpulan tentang penggunan deiksis pada karangan narasi siswa.

\section{HASIL DAN PEMBAHASAN}

Berdasarkan ruang lingkup penganalisisan, penulis akan menyajikan analisis penggunaan deiksis dari 
karangan narasi siswa kelas X SMK Wira Buana 2. Deiksis yang akan dianalisis terdiri atas tiga jenis. yaitu deiksis persona orang pertama, kedua, dan ketiga.

Tabel 1 Temuan Penelitian

\begin{tabular}{lrr}
\hline Deiksis & & \\
Persona & $\mathbf{5 1 4}$ & $\mathbf{1 0 0 \%}$ \\
Orang pertama & 496 & $96.50 \%$ \\
Orang kedua & 2 & $0.39 \%$ \\
Orang ketiga & 16 & $3.11 \%$ \\
\hline
\end{tabular}

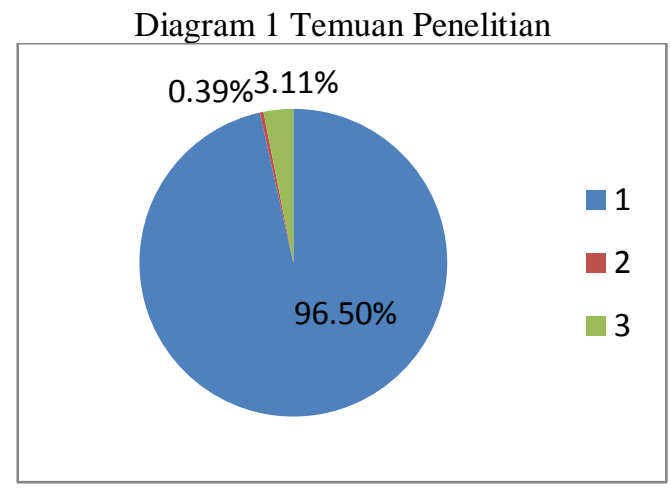

Deiksis persona merupakan peserta yang memiliki peran dalam kegiatan tutur. peran dalam kegiatan berbahasa dapat dibedakan menjadi tiga yaitu persona pertama, persona kedua dan persona ketiga.

\section{Persona Pertama}

Berdasarkan hasil deskripsi penelitian di atas, terdapat kata-kata yang berdeiksis yang masuk kategori persona pertama, seperti saya, aku, -ku, kami dan kita yang telah digunakan siswa kelas X SMK Wira Buana 2 pada hasil karangan narasi. Dalam penelitian ini persona pertama tunggal ditemukan dalam bentuk kata saya, aku dan morfem terikat lekat kanan yaitu $-k u$. Kata saya yang dimaksud dalam karangan-karangan tersebut mengacu pada pengarang atau pembicara yang sedang menceritakan dirinya sendiri. Hal ini sesuai dengan pendapat Ihsan (2011:75) yang menyatakan bahwa kata ganti seperti $I$, me orang pertama tunggal. Jika dibandingkan dengan kata yang lain, kata saya dan $a k u$ adalah kata yang paling sering digunakan oleh siswa kelas $X$ di SMK Wira Buana 2.

Di bawah ini terdapat beberapa penggunaan kata-kata deiksis tersebut, yaitu:

1. Pada hari Sabtu saya pergi ke Kebun Raya Bogor.

2. Saat bertemu nenek, nenek langsung memelukku dan mencium pipiku.

3. Aku berjalan ke halaman depan rumah tepat dihadapanku ada sebuah jalan besar untuk berlalu lintas dari kejauhan tampak sawah.

4. Saya dan keluarga saya pergi berlibur kerumah saudara saya.

Terdapat penggunaan persona pertama jamak, yaitu kata kami dan kita. Kata kami mengacu pada diri masingmasing siswa dan orang lain seperti keluarga, teman, atau saudara dari siswa tersebut. Kemudian kata kita mengacu pada diri masing-masing siswa sebagai orang pertama, orang lain seperti keluarga atau teman dari siswa sebagai orang ketiga, termasuk pihak kedua, yaitu pembaca, sehingga kata kita memiliki cakupan yang lebih luas dari kata kami. Sesuai dengan pendapat Ihsan (2011:75) yang menyatakan we, us merupakan orang pertama jamak. Jika dibandingkan, kata kami dan kita memiliki perbedaan makna. Akan tetapi, masih terdapat siswa yang menggunakan kata tersebut dengan tidak tepat dengan menganggap kedua kata tersebut sama saja.

Di bawah ini terdapat beberapa penggunaan kata-kata deiksis tersebut, yaitu:

1. Kita sebagai generasi muda seharusnya melindungi hewan-hewan tersebut bukan merusak dan mengusik habitatnya agar anak cucu kita dapat melihatnya. 
2. Tidaklah lama perut kami terasa keroncongan dan segeralah kami mencari tempat makan lesehan.

3. Setelah tanpa kami sadari ternyata ada teman kami yang tertinggal di belakang dan kami berhenti sejenak untuk menghubungi teman kami yang tertinggal itu.

\section{Persona Kedua}

Berdasarkan hasil penelitian, terdapat kata-kata yang berdeiksis yang masuk kategori persona kedua, seperti kata mereka yang telah digunakan siswa kelas X SMK Wira Buana 2. Kata kamu dan kau termasuk dalam kata penunjuk persona kedua yang berbentuk tunggal. Kata tersebut dapat digunakan oleh pihak pertama untuk menunjuk orang lain atau tokoh lain dalam cerita. Hal ini sependapat dengan Ihsan (2011:75) yang menyatakan you sebagai orang kedua tunggal. Namun, berdasarkan hasil karangan narasi yang dibuat oleh siswa SMK Wira Buana 2, kata kamu dan kau sama sekali tidak digunakan.

Kata kalian merupakan kata deiksis persona kedua jamak yang dapat digunakan oleh penulis sebagai pihak pertama untuk menunjuk pihak kedua yang berjumlah lebih dari satu orang atau kelompok. baik itu merujuk pembaca, ataupun orang lain dalam sebuah dialog dalam cerita. Semua tergantung pada konteksnya. Hal ini sependapat dengan Ihsan (2011:75) yang menyatakan you sebagai deiksis orang kedua jamak. Di bawah ini adalah kutipan dari hasil karangan narasi siswa yang menggunakan kata kalian, yaitu:

1. Kami pun tiba di sana dan snorkling dan kalian tahu apa? Ya! Hujan pun turun. Deras, dan semakin deras, sehingga ada satu kapal yang sampai terbelah menjadi bukan bentuk kapal lagi.

2. Apakah kalian bisa bayangkan tenggelam ditengah laut tiba-tiba?

\section{Persona Ketiga}

Berdasarkan hasil penelitian, terdapat kata-kata yang berdeiksis yang masuk kategori persona ketiga, seperti yang telah digunakan siswa kelas X SMK Wira Buana 2. Kata dia, ia dan -nya merupakan deiksis persona ketiga yang digunakan siswa dalam membuat karangan narasi. Kata tersebut digunakan untuk menunjuk pihak lain seperti keluarga, teman atau tokoh lain dalam cerita. Hal ini sesuai dengan pandangan dari Ihsan (2011:75) yang menyatakan bahwa he, him, she, her merupakan orang ketiga laki-laki dan perempuan.

Di bawah ini adalah kutipan dari hasil karangan narasi siswa yang menggunakan kata tersebut, yaitu:

1. Akhirnya dia pun membantu saya membuat kue.

2. Aku dan orang-orang disekitar langsung menolongnya.

3. Dari kejauhan pula terlihat seorang petani yang sedang membajak sawahnya yang belum ditanami tumbuhan, dan ada juga petani yang sedang mencari rumput untuk makan binatang peliharaannya seperti kambing, sapi, dan kerbau.

4. Setelah itu pun saya dan teman-teman muter balik untuk ke lokasi, pas sampai di lokasi ternyata teman kami yang bilang jatuh dari motor tersebut, teman kami itu yang berbohong, pas sempat tau teman saya pun sedikit kesal terhadap temannya yang berbohong, lalu ia memarahi temannya itu dengan emosinya.

Kata mereka merupakan deiksis persona ketiga jamak yang digunakan untuk menunjuk sekelompok orang atau sekelompok tokoh dalam karangan. Hal ini sesuai dengan pandangan dari Ihsan (2011:75) yang menyatakan bahwa they dan them merupakan orang ketiga jamak. 
Di bawah ini adalah kutipan dari hasil karangan narasi siswa yang menggunakan kata mereka, yaitu: Mereka tidak mau hal-hal yang tidak diinginkan kembali terjadi.

\section{SIMPULAN}

Berdasarkan hasil analisis yang telah dilakukan pada karangan narasi yang dibuat oleh siswa kelas X SMK Wira Buana 2, ditemukan banyaknya penggunaan kata berdeiksis persona dengan total 514 temuan. Sebagai perinciaanya, penggunaan deiksis persona pertama sebanyak 496 kata dengan hasil persentase sebesar $96.50 \%$. Penggunaan deiksis persona kedua sebanyak 2 kata dengan hasil persentase $0,39 \%$ dan penggunaan deiksis persona ketiga sebanyak 16 kata dengan hasil persentase $3,11 \%$. Deiksis persona pertama lebih dominan dibandingkan dengan deiksis persona kedua dan deiksis persona ketiga.

\section{DAFTAR PUSTAKA}

Alwi, H. dkk. (2003). Tata bahasa baku bahasa indonesia. Cetakan 5. Jakarta: Balai Pustaka.
Departemen Pendidikan Nasional. (2011). Kamus besar bahasa indonesia. Jakarta: PT Gramedia.

Ihsan, D. (2011). Pragmatik, analisis wacana dan guru bahasa. Palembang:Universitas Sriwijaya.

Kridalaksana, H. (2009). Kamus linguistik. Jakarta: PT Gramedia.

Kushartanti dkk. (2005). Pesona bahasa: langkah awal memahami bahasa. Jakarta: PT Gramedia.

Putrayasa, I. B. (2014). Pragmatik. Yogyakarta: Graha Ilmu.

Verhaar, J. W. M. dkk. (2006). Asasasas linguistik umum. Yogyakarta: Gajah Mada University Press.

Yule, G. (2006). Pragmatik. Yogyakarta: Pustaka Pelajar. 